\title{
Atuação Multiprofissional com Alunos no Eixo Trabalho em Saúde: Processo de Aprendizagem Pela Prática
}

\author{
Lemes, Maria Helena Carvalho; Nakabayashi, Alex; Uchoa, Lucia; Aveiro, Mariana \\ Universidade Federal de São Paulo — mariahelenaclemes@gmail.com
}

Introdução: a Universidade Federal de São Paulo (UNIFESP) campus Baixada Santista desde o primeiro ano da graduação oferece a oportunidade dos alunos apreenderem pela prática através dos seus eixos. o eixo trabalho em saúde no terceiro ano possibilita que os alunos em equipe multiprofissional sigam um caso indicado pela equipe de um equipamento de saúde, assim a usuária P. foi encaminhada para atendimento por ser diagnosticada com Transtorno do Pânico e Depressão após sentir os primeiros sintomas como: taquicardia e mal estar físico. Tais fatores foram decorrentes da morte de um primo próximo de P., o qual era considerado como um irmão. com isso, P. Iniciou o tratamento sendo atendida por um psiquiatra e posteriormente por um psicólogo da rede do SUS. a princípio foram-Ihe receitados medicamentos para amenizar as crises que vinha sofrendo. a equipe de estudantes da a acompanha desde 2011, e foi observado que tanto o TP e a depressão afetam não só o corpo do sujeito, mas também seus pensamentos, emoções e sua forma de se relacionar no e com o mundo. Nesse período P. Foi afastada do emprego e também passou por uma gravidez. Atualmente, seu filho está com um ano de idade e P. Ainda encontra-se afastada do trabalho sem receber benefício algum, possuindo apenas ajuda financeira da família e das vendas de bijuterias que ela mesma produz. Objetivos: o principal objetivo do acompanhamento terapêutico é ampliar a cadeia de cuidado em saúde, centrada no indivíduo, possibilitando seu acesso a outras redes de apoio. e com isso promover a autonomia do sujeito a fim de fortalecer suas relações sociais no meio em que vive. Métodos: Além da utilização de medicamentos por $P$., ela também passou pelo atendimento individual com o psicólogo e visitas domiciliares pela equipe multidisciplinar de estudantes. a equipe foi composta pelas diferentes áreas da saúde como: psicologia, terapia ocupacional, fisioterapia e educação física. nas visitas eram realizadas ações para criação de vínculo com a usuária e fortalecimento da autonomia por parte da mesma. Além disso, os estudantes se reuniam no serviço de Atenção Básica para discussão do caso com intuito de dar continuidade ao processo, centrando nas reais necessidades do sujeito acompanhado. Resultados: As ações desenvolveram-se a partir das relações traçadas com P., as quais foram importantes momentos de escuta por parte dos estudantes para criação e efetivação do vínculo entre eles e a usuária. Tais encontros possibilitaram a atribuição de significados subjetivos, tanto por P. como por seus acompanhantes. com isso, as visitas serviram para que P. conseguisse superar as crises vivenciadas nesta fase de sua vida e atualmente foi nítida sua transformação na maneira de encarar tal processo. Conclusão: a experiência de traçar coletivamente em equipe um projeto terapêutico singular fez com que ampliasse a percepção dos estudantes em relação a essa forma de tratar o sujeito. Além disso, foi muito marcante observar a evolução da usuária durante todo o processo e vínculo estabelecido com a mesma.

Lemes, Maria Helena Carvalho; Nakabayashi, Alex; Uchoa, Lucia; Aveiro, Mariana. Atuação Multiprofissional com Alunos no Eixo Trabalho em Saúde: Processo de Aprendizagem Pela Prática. In: Anais do Congresso Internacional de Humanidades \& Humanização em Saúde [= Blucher Medical Proceedings, num.2, vol.1]. São Paulo: Editora Blucher, 2014. ISSN 2357-7282

DOI 10.5151/medpro-cihhs-10610 